\title{
PUBLIC AWARENESS, UNDERSTANDING AND ATTITUDES TOWARDS EPILEPSY IN MONTENEGRO
}

\author{
Sanja Vodopić ${ }^{1,2}$ and Slavica Vujisicíc, \\ ${ }^{1}$ Clinical Department of Neurology, Clinical Centre of Montenegro; \\ ${ }^{2}$ School of Medicine, University of Montenegro, Podgorica, Montenegro
}

\begin{abstract}
SUMMARY - Stigma remains a distressing consequence of epilepsy worldwide. We assessed stigma markers among citizens of Montenegro. Randomly selected adults aged 18 to 65 were interviewed using a 10-item questionnaire, which had been used in similar settings. Descriptive statistics, $\chi^{2}$-test and Fisher exact test were used in order to identify factors associated with negative attitudes. After exclusions and refusals, the questionnaire was administered to 1000 people, $91 \%$ of whom had heard about epilepsy. Less than half knew someone with epilepsy and $31.5 \%$ had witnessed a seizure. One-fifth would object if their child played with a person who had epilepsy and three-quarters would object if their child married a person with epilepsy. Forty percent believed people with epilepsy should be employed in the same way as everybody else. Fewer than $8 \%$ of respondents thought epilepsy was a form of insanity. Over $80 \%$ favored brain disease as a cause of epilepsy and $95 \%$ chose convulsions to be a major feature of an epileptic attack. General awareness of epilepsy in Montenegro is similar to that in other countries. Understanding epilepsy is relatively good but the results suggest that there still are negative attitudes towards people with epilepsy.
\end{abstract}

Key words: Epilepsy; Health knowledge, attitudes, practice; Public opinion; Social stigma; Montenegro

\section{Introduction}

Epilepsy is a chronic neurologic disorder that affects over 50 million people worldwide and knows no racial, national or geographic boundaries ${ }^{1}$ It is also one of the most misunderstood disorders ${ }^{2}$. Lack of understanding and ignorance about epilepsy are associated with negative attitudes towards people with epilepsy and a tendency to stigmatization ${ }^{2}$ Regardless of history, economy and social norms, the concept of stigma is universal across different cultures. Labeling is profoundly embedded into social and cultural milieu, therefore dealing with social factors might be the key to uncovering public misconceptions about epilepsy.

Despite obvious disparities present between rich and resource poor countries, it is vital to share, com-

Correspondence to: Prof. Slavica Vujisić, $M D, P h D$, Clinical Department of Neurology, Clinical Centre of Montenegro, Ljubljanska bb, 81000 Podgorica, Montenegro

E-mail: svujisic@ac.me

Received April 13, 2016, accepted May 10, 2017 pare and contrast study findings if we want to alleviate stigmatization and change public attitudes. Public surveys could be the starting point in initiating educational campaigns. Surveys should be created based on current knowledge and attitudes among members of the community. Several countries have carried out these educational campaigns and the results demonstrated encouraging changes ${ }^{3,4}$.

The aim of this study was to estimate the Montenegrin public awareness, understanding and attitudes towards epilepsy, and to correlate the findings with the responder's social background.

\section{Subjects and Methods}

\section{Subjects}

The population of Podgorica, the capital of Montenegro, is about 185,000 people ${ }^{5}$ The study group comprised 1326 adults aged 18 to 65, living in Podgorica. For the purpose of the study, the city was divided into 
three administrative and geographically different areas (urban, suburban and rural regions). The number of responders was proportionate to the area population, e.g., more responders were selected from the city and suburban regions, and fewer from rural settlements. Random selection was ensured by choosing households randomly (random walk method from randomly selected starting points within three areas) and random selection of respondents within selected households. The study was conducted between November 2015 and February 2016. We excluded people with epilepsy or those who had relatives with epilepsy.

\section{Methods and statistical analysis}

In face-to-face interviews, participants were asked to respond to a 10 -item questionnaire. Participation was voluntary; participants provided signed informed consent, but the responses were anonymous. The questionnaire consisted of 4 categories: demographic data of responders, familiarity with epilepsy, understanding of epilepsy, and attitudes towards epilepsy. Each category consisted of several questions (Appendix 1). Some questions were designed so that responders could choose among "yes", "no" or "I don't know", while others were allowed multiple answers. The questions were taken from a questionnaire previously used in China ${ }^{6}$. The questionnaire was translated into Montenegrin from the English version and went through translation and back-translation. If responders had problems understanding the exact meaning of the questions, interviewers were allowed to elaborate.

Data were entered into the computer using Excel program and analyzed by Statistical Package for Social Sciences (SPSS) 16.0 software (SPSS, Inc., Chicago, IL, USA). Continuous variables were expressed as the range, mean and standard deviation, whereas categorical variables were presented as frequencies (\%). We used $\chi^{2}$-test and Fisher exact test to examine the association between the frequency of positive responses and dependent variables.

\section{Results}

Of 1326 people pre-selected, 265 refused to take part and 61 were excluded (as they had epilepsy or family members had epilepsy), leaving 1000 people having completed the questionnaire. Socio-demo-
Table 1. Socio-demographic background of participants

\begin{tabular}{|l|l|}
\hline Number of participants & 1000 \\
\hline Gender & 481 \\
Fale & 519 \\
\hline Age (yrs) & \\
$18-24$ & 483 \\
$25-34$ & 216 \\
$35-44$ & 165 \\
$45-54$ & 76 \\
$55-65$ & 60 \\
\hline Education & \\
Primary school & 67 \\
Secondary school & 281 \\
University or higher & 652 \\
\hline Marital status & \\
Married & 275 \\
Single & 696 \\
Divorced/widowed/separated & 29 \\
\hline Residence & \\
Urban & 653 \\
Suburban & 284 \\
Rural & 63 \\
\hline
\end{tabular}

graphic background data of participants are presented in Table 1 . The mean $( \pm \mathrm{SD})$ age was $30.32 \pm 12.18$ years (range 18 to 65 years). There were slightly more females (51.9\%) than males. Less than one-third (27.5\%) were married, mostly women (52.7\%). Sixty-five percent were studying or had finished college. Most (65.3\%) participants lived in an urban area.

More than ninety percent (Q1, 91\%) of all participants had heard of epilepsy. Those having provided negative answer to this question were excluded from further statistical analysis. Younger people aged 25 to 34 , as well as older respondents provided positive answers. Less than half of those who had heard about epilepsy (Q2, 42.6\%) knew someone with epilepsy. Older participants $(\mathrm{p}<0.0001)$, participants with elementary school, participants who were married and participants living in rural area answered "yes" to this question $(\mathrm{p}<0.0001$ all). Just over thirty percent of study population (Q3, 31.5\%) had witnessed a seizure. They were more likely to be female, older participants, 
Table 2. Familiarity with epilepsy among surveyed participants

\begin{tabular}{|c|c|c|c|c|c|}
\hline & & $\begin{array}{l}\text { Q1: are you } \\
\text { familiar with } \\
\text { epilepsy? }\end{array}$ & $\begin{array}{l}\text { Those familiar } \\
\text { with epilepsy }\end{array}$ & $\begin{array}{l}\text { Q2: have you } \\
\text { known anyone } \\
\text { with epilepsy? }\end{array}$ & $\begin{array}{l}\text { Q3: have you } \\
\text { seen anyone } \\
\text { having a seizure? }\end{array}$ \\
\hline & & Yes & & Yes & Yes \\
\hline Total & 1000 & 910 & & $426(47 \%)$ & $315(35 \%)$ \\
\hline Gender & & $p=0.66$ & & $\mathrm{p}=0.32$ & $\mathrm{p}<0.0001$ \\
\hline Male & 481 & $440(91 \%)$ & 440 & $198(45 \%)$ & $121(28 \%)$ \\
\hline Female & 519 & $470(91 \%)$ & 470 & $228(49 \%)$ & $194(41 \%)$ \\
\hline Age (yrs) & & $\mathrm{p}<0.0001$ & & $\mathrm{p}<0.0001$ & $\mathrm{p}<0.0001$ \\
\hline $18-24$ & 483 & $419(87 \%)$ & 419 & $112(27 \%)$ & $86(21 \%)$ \\
\hline $25-34$ & 216 & $209(97 \%)$ & 209 & $113(54 \%)$ & $82(39 \%)$ \\
\hline $35-44$ & 165 & $157(95 \%)$ & 157 & $103(66 \%)$ & $70(45 \%)$ \\
\hline $45-54$ & 76 & $67(88 \%)$ & 67 & $49(73 \%)$ & $36(54 \%)$ \\
\hline $55-65$ & 60 & $58(97 \%)$ & 58 & $49(84 \%)$ & $41(71 \%)$ \\
\hline Education & & $\mathrm{p}=0.22$ & & $\mathrm{p}<0.0001$ & $\mathrm{p}<0.0001$ \\
\hline Primary school & 67 & $57(85 \%)$ & 57 & $50(88 \%)$ & $35(61 \%)$ \\
\hline Secondary school & 281 & $258(92 \%)$ & 258 & $185(72 \%)$ & $140(54 \%)$ \\
\hline University or higher & 652 & $595(91 \%)$ & 595 & $191(32 \%)$ & $140(24 \%)$ \\
\hline Marital status & & $\mathrm{p}=0.10$ & & $\mathrm{p}<0.0001$ & $\mathrm{p}<0.0001$ \\
\hline Married & 275 & $259(94 \%)$ & 259 & $181(70 \%)$ & $133(51 \%)$ \\
\hline Single & 696 & $622(93 \%)$ & 622 & $224(36 \%)$ & $165(27 \%)$ \\
\hline Divorced/separated/widowed & 29 & $29(100 \%)$ & 29 & $21(72 \%)$ & $17(59 \%)$ \\
\hline Residence & & $\mathrm{p}=0.12$ & & $\mathrm{p}<0.0001$ & $\mathrm{p}<0.0001$ \\
\hline Urban & 653 & $600(92 \%)$ & 600 & $249(42 \%)$ & $176(29 \%)$ \\
\hline Suburban & 284 & $257(90 \%)$ & 257 & $136(53 \%)$ & $113(44 \%)$ \\
\hline Rural & 63 & $53(84 \%)$ & 53 & $41(77 \%)$ & $26(49 \%)$ \\
\hline
\end{tabular}

participants with a lower level of education, married participants $(p<0.0001$ all $)$, and interviewed people living in rural area $(\mathrm{p}<0.05)$ (Table 2$)$.

One-fifth of all participants (Q4, 22.4\%) would object if their child played with a person who had epilepsy. Those aged 55 to 65 ( $p=0,004)$, participants with primary level of education, married people and participants from rural areas objected significantly more than others $(p<0.0001 \mathrm{all})$. Three-quarters of the study population (Q5, 76.2\%) would object if their child married a person with epilepsy. Younger participants and respondents coming from urban settlement would object less compared to older ones or participants from rural area, whereas respondents with lower level of education would object more $(\mathrm{p}<0.0001$ all). Forty- one percent of surveyed participants (Q6, 40.6\%) believed people with epilepsy should be employed as everybody else. The respondents were younger people, single participants, respondents with university diploma, and participants living in urban area (Table 3).

Less than $8 \%$ of respondents (Q7, 7.8\%) thought epilepsy was a form of insanity. Respondents were more likely to be older, participants with lower level of education (primary school mostly) and respondents living in rural areas $(\mathrm{p}<0.0001$ all). Just over $10 \%$ of participants $(\mathrm{Q} 8,12 \%)$ could not name the cause of epilepsy. In this study, $84 \%$ favored brain disease/disorder/injury as the cause of epilepsy; 152 participants believed epilepsy was hereditary, and the rest thought birth defects and mental/emotional stress were the 
Table 3. Attitudes toward people with epilepsy among interviewed respondents

\begin{tabular}{|c|c|c|c|c|c|}
\hline & & $\begin{array}{l}\text { Q4: object to } \\
\text { children playing? }\end{array}$ & $\begin{array}{l}\text { Q5: object to } \\
\text { child marrying? }\end{array}$ & $\begin{array}{l}\text { Q6: should be } \\
\text { employed? }\end{array}$ & $\begin{array}{l}\text { Q7: do you think } \\
\text { epilepsy is insanity? }\end{array}$ \\
\hline & $\begin{array}{l}\text { Familiar } \\
\text { with epilepsy }\end{array}$ & Yes & Yes & Yes & Yes \\
\hline Total & 910 & 204 & 693 & 406 & 71 \\
\hline $\begin{array}{l}\text { Gender } \\
\text { Male } \\
\text { Female }\end{array}$ & $\begin{array}{l}440 \\
470\end{array}$ & $\begin{array}{l}p=0.81 \\
97(22 \%) \\
107(23 \%)\end{array}$ & $\begin{array}{l}p=0.48 \\
340(77 \%) \\
353(75 \%)\end{array}$ & $\begin{array}{l}\mathrm{p}=0.39 \\
203(46 \%) \\
203(43 \%)\end{array}$ & $\begin{array}{l}\mathrm{p}=0.46 \\
31(7.1 \%) \\
40(8.5 \%)\end{array}$ \\
\hline $\begin{array}{c}\text { Age (yrs) } \\
18-24 \\
25-34 \\
35-44 \\
45-54 \\
55-65\end{array}$ & $\begin{array}{l}419 \\
209 \\
157 \\
67 \\
58\end{array}$ & $\begin{array}{l}\mathrm{p}=0.004 \\
78(19 \%) \\
49(23 \%) \\
35(22 \%) \\
18(27 \%) \\
24(41 \%)\end{array}$ & $\begin{array}{l}\mathrm{p}<0.0001 \\
271(65 \%) \\
166(79 \%) \\
139(89 \%) \\
60(90 \%) \\
57(98 \%) \\
\end{array}$ & $\begin{array}{l}\mathrm{p}<0.0001 \\
230(55 \%) \\
82(39 \%) \\
60(38 \%) \\
22(33 \%) \\
12(21 \%)\end{array}$ & $\begin{array}{l}\mathrm{p}<0.0001 \\
10(2.4 \%) \\
19(9.1 \%) \\
12(7.6 \%) \\
10(15 \%) \\
20(34 \%)\end{array}$ \\
\hline $\begin{array}{l}\text { Education } \\
\text { Primary school } \\
\text { Secondary school } \\
\text { University or higher }\end{array}$ & $\begin{array}{l}57 \\
258 \\
595 \\
\end{array}$ & $\begin{array}{l}\mathrm{p}<0.0001 \\
38(67 \%) \\
51(20 \%) \\
115(19 \%)\end{array}$ & $\begin{array}{l}\mathrm{p}<0.0001 \\
57(100 \%) \\
226(88 \%) \\
410(69 \%) \\
\end{array}$ & $\begin{array}{l}p<0.0001 \\
6(11 \%) \\
73(28 \%) \\
327(55 \%)\end{array}$ & $\begin{array}{l}\mathrm{p}<0.0001 \\
38(67 \%) \\
31(12 \%) \\
2(0.3 \%)\end{array}$ \\
\hline $\begin{array}{l}\text { Marital status } \\
\text { Married } \\
\text { Single } \\
\text { Divorced/ } \\
\text { separated/ } \\
\text { widowed } \\
\end{array}$ & $\begin{array}{l}259 \\
622 \\
29\end{array}$ & $\begin{array}{l}p<0.0001 \\
86(33 \%) \\
113(18 \%) \\
5(17 \%)\end{array}$ & $\begin{array}{l}\mathrm{p}<0.0001 \\
240(93 \%) \\
425(68 \%) \\
28(97 \%)\end{array}$ & $\begin{array}{l}\mathrm{p}<0.0001 \\
79(31 \%) \\
320(51 \%) \\
7(24 \%)\end{array}$ & $\begin{array}{l}\mathrm{p}<0.0001 \\
42(16 \%) \\
28(4.5 \%) \\
1(3.4 \%)\end{array}$ \\
\hline $\begin{array}{l}\text { Residence } \\
\text { Urban } \\
\text { Suburban } \\
\text { Rural }\end{array}$ & $\begin{array}{l}600 \\
257 \\
53 \\
\end{array}$ & $\begin{array}{l}\mathrm{p}<0.0001 \\
115(19 \%) \\
50(19 \%) \\
39(74 \%) \\
\end{array}$ & $\begin{array}{l}\mathrm{p}<0.0001 \\
437(73 \%) \\
203(79 \%) \\
53(100 \%)\end{array}$ & $\begin{array}{l}\mathrm{p}<0.0001 \\
314(52 \%) \\
82(32 \%) \\
10(19 \%)\end{array}$ & $\begin{array}{l}\mathrm{p}<0.0001 \\
19(3.2 \%) \\
24(9.3 \%) \\
28(53 \%)\end{array}$ \\
\hline
\end{tabular}

cause of seizures. Ninety-five percent of respondents chose convulsions/shaking in multiple-choice/singleanswer format, and 351 people listed loss of consciousness. All those who had heard of epilepsy would advise a friend or relative with epilepsy to see a physician. A small number (4\%) thought epilepsy was untreatable. Nine percent would consult an herbal medicine practitioner. Those who would only advise medical treatment were more likely to be younger people, female participants, respondents with university diploma, and people from urban area $(\mathrm{p}<0.0001$ all).

\section{Discussion}

Surveys about public understanding, awareness and attitudes towards epilepsy have not previously been performed in Montenegro. It seems that Montenegrins are familiar with epilepsy, as reported from other countries $^{3,4,7-13}$. Young people seem to be quite aware (87\%), although older participants were more familiar (97\%). Possible explanation for the positive correlation between age and awareness might be attributed to the influence of mass media, notably during the past decade. Fewer than half of all participants knew someone with epilepsy, which is less than the proportion report-

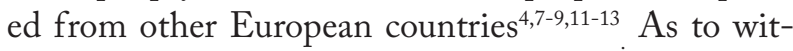
nessing an epileptic seizure, results are similar to neighboring countries $(45 \%)^{7}$, but less than developed countries $(50.8 \%)^{4,9}$.

Attitudes towards people with epilepsy tended to be more negative in our population. More than onefifth objected to their children associating with some- 
one with seizures, a proportion considerably higher than reported from other surveys s, $^{3,7-9,13}$ Even more respondents would object to their children marrying someone with epilepsy and this is seen even in the most educated people. In a study by Degirmenci et al., $70 \%$ of respondents would not permit their healthy child to marry a person with epilepsy ${ }^{14}$.

Forty percent of surveyed participants thought people with epilepsy should be employed in jobs like others. This unexpectedly positive attitude towards employment can only be explained by their poor knowledge of epilepsy. Our result is less favorable than that reported in a Hungarian survey ${ }^{4}$, from Finland ${ }^{9}$, $\mathrm{UK}^{10}$, Greece $^{11}$ and a Czech study ${ }^{3}$.

The understanding of epilepsy was better than in other European countries. In a survey by Diamantopoulos et al. ${ }^{11}, 15 \%$ of the participants believed that epilepsy was a form of insanity. In a Hungarian study, even more respondents (17.2\%) shared the same opinion $^{4}$. Compared to data from Croatia ${ }^{8}$ and Bosnia and Herzegovina $^{7}$, our results are comparable but less favorable $(7.8 \%$ vs. $5.7 \%$ vs. $2.5 \%)$. Despite the negative attitudes described previously, this finding suggests the importance of public education. In this study, $84 \%$ of the participants considered a brain disease/disorder/ injury to be the main cause of epilepsy, a higher percentage than in Hungarian $(20.1 \%)^{4}$, Croatian $(23.2 \%)^{8}$ and UK $(57 \%)^{10}$ surveys, but less than reported from a Greek survey ${ }^{11}$. Respondents from rural areas strongly believed epilepsy was a hereditary disorder. This response once again has highlighted the importance of education. People from rural areas are quite traditional, but we believe that aggressive educational campaign might change their attitude towards people with epilepsy, using close relationships among inhabitants. In the Croatian survey, $22.1 \%$ of all participants listed heredity as a cause of epilepsy, but unlike our study, those participants exclusively chose that answer. ${ }^{8}$. In the Hungarian survey, $1.5 \%$ of respondents believed epilepsy was hereditary, but they also chose this answer alone ${ }^{4}$. We believe that cross cultural and socio-demographic discrepancies might partly explain large differences between our and results from other countries.
More than $90 \%$ of our participants chose convulsions/shaking to be the cause of epilepsy in multiplechoice/single-answer format, a higher rate than in the studies from Croatia ${ }^{8}$, Hungary ${ }^{4}$ and the $\mathrm{UK}^{10}$. An additional 351 respondents believed an epileptic attack was a combination of convulsions/shaking and loss of consciousness. This result thus supports the wellknown misconception that "people with epilepsy shake". Generalized tonic-clonic seizures are not the most prevalent seizures, yet they are the first and usually the only one people think of when they hear the word "epilepsy" or "epileptic seizure". A small percentage of our participants encircled answers which described partial epileptic seizures, but they already knew someone with this kind of seizure.

\section{Strengths and limitations of the study}

This was a large population based study, with a high response rate $(>70 \%)$. Replication of questions from earlier studies gave some useful information. The explanatory power of the study is limited by the possibility that declared beliefs of respondents may differ from held beliefs.

Podgorica is a university centre for the entire country. Therefore, most of the people who study also live in the capital. This is a limitation factor of this study and therefore these results could not be representative for the entire country. Yet, they do reflect the opinion of young Montenegrin citizens.

\section{Conclusion}

Public familiarity with and understanding of epilepsy are similar to those in other developed countries. Attitudes towards epilepsy were negative and we determined negative predictors. Information campaigns are urgently needed in Montenegro. These campaigns should be designed to fight some of deeply rooted prejudices, especially in rural areas. Processes that might change current negative attitudes should be reinforced. 


\section{Appendix 1}

Q1. Have you ever heard of or read about the disease called "epilepsy" or "convulsive seizures" (fits)?

1. yes

2. no

Q2. Did you ever know anyone who had epilepsy?
1. yes
2. no
3. not familiar with epilepsy

Q3. Have you ever seen anyone who was having a seizure?
1. yes
2. no
3. not familiar with epilepsy

Q4. Would you object to having any of your children in school or at play associate with persons who sometimes had seizures (fits)?
1. yes
2. no
3. not familiar with epilepsy

Q5. Would you object to your son or daughter marrying a person who sometimes had seizures (fits)?
1. yes
2. no
3. not familiar with epilepsy

Q6. Do you think people with epilepsy should or should not be employed in jobs like other people?
1. should
2. should not
3. no opinion
4. not familiar with epilepsy

Q7. Do you think epilepsy is a form of insanity or not?
1. yes
2. no
3. not familiar with epilepsy

Q8. What do you think is the cause of epilepsy? (multiple answers are allowed)

1. don't know

2. brain disease, disorder or injury

3. hereditary, inherited disease

4. birth defect

5. mental or emotional stress, disorder

6. blood disorder

7. other (please specify)

8. not familiar with epilepsy

Q9. What do you think an epileptic attack is (multiple answers are allowed)

1. convulsions, shaking

2. loss of consciousness

3. transient changes of behavior

4. period of amnesia

5. don't know

Q10. If your relatives or friends have epilepsy, what kind of treatment would you suggest? (multiple answers are allowed)

1. ask for an "MD"

2. to get medicine from drugstore by him/herself

3. ask for an herbal medicine doctor

4. acupuncture

5. surgical treatment

6. ask for God's help

7. think "epilepsy is untreatable"

8. no need to treat

9. don't know what to recommend

\section{References}

1. World Health Organization. Fact sheet 999: Epilepsy. Geneva: WHO, 2012. (generic)

2. McLin WM, de Boer HM. Public perception about epilepsy. Epilepsia. 1995;36:957-9. doi: 10.1111/j.1528-1157.1995.tb 00952.x

3. Novotná I, Rektor I. The trend in public attitudes in the Czech Republic towards persons with epilepsy. Eur J Neurol. 2002; 9(5):535-40. doi: 10.1046/j.1468-1331.2002.00466.x

4. Mirnics Z, Czikora G, Zavecz T, Halasz P. Changes in public attitudes toward epilepsy in Hungary: results of surveys conducted in 1994 and 2000. Epilepsia. 2001;42:86-93. doi: 10.1046/j.1528-1157.2001.18000.x

5. Census of Population, Households and Dwellings in Montenegro No. 83, 2011. Available from: http://www.monstat.org/ userfiles/file/popis2011/saopstenje/saopstenje\%281\%29.pdf

6. Li S, Wu J, Wang W, Jacoby A, de Boer H, Sander JW. Stigma and epilepsy: the Chinese perspective. Epilepsy Behav. 2010; 17(2):242-5. doi: 10.1016/j.yebeh.2009.12.015 
7. Bagić A, Bagić D, Živković I. First population study of the general public awareness and perception of epilepsy in Bosnia and Herzegovina. Epilepsy Behav. 2009;14(1):154-61. doi: 10.1016/j.yebeh.2008.10.007

8. Bagić A, Bagić D, Živković I. First population study of the general public awareness and perception of epilepsy in Croatia. Epilepsy Behav. 2009;15:170-8. doi: org/10.1016/j.yebeh.2009.02.044

9. Iivanainen M, Uutela A, Vilkkumaa I. Public awareness and attitudes toward epilepsy in Finland. Epilepsia. 1980;21(4): 413-23. doi: 10.1111/j.1528-1157.1980.tb04089.x

10. Jacoby A, Gorry J, Gamble C, Baker GA. Public knowledge, private grief: a study of public attitudes to epilepsy in the United Kingdom and implications for stigma. Epilepsia. 2004; 45(11):1405-15. doi: 10.1111/j.0013-9580.2004.02904.x
11. Diamantopoulos N, Kaleyias J, Tzoufi M, Kotsalis C. A survey of public awareness, understanding, and attitudes toward epilepsy in Greece. Epilepsia. 2006;47:2154-64. doi: 10.1111/ j.1528-1167.2006.00891.x

12. Demirci S, Donmez CM, Gundogar D, Baydar CL. Public awareness of, attitudes toward, and understanding of epilepsy in Isparta, Turkey. Epilepsy Behav. 2007;11:427-33. doi: 10.1016/j.yebeh.2007.08.005

13. Spatt J, Bauer G, Baumgartner C, et al.; for the Austrian Section of the International League Against Epilepsy. Predictors for negative attitudes toward subjects with epilepsy: a representative survey in the general public in Austria. Epilepsia. 2005;46:736-42. doi: 10.1111/j.1528-1167.2005.52404.x

14. Degirmenci Y, Kabay CS , Yilmaz Z, Bakar C, Karaman OH. Perception of epilepsy in Turkey in the light of two different cities. Acta Clin Croat. 2013;52:59-67.

Sažetak

\section{JAVNA SVIJEST, RAZUMIJEVANJE I STAVOVI PREMA EPILEPSIJI U CRNOJ GORI}

\section{S. Vodopič i S. Vujisić}

Stigma ostaje uznemiravajuća posljedica epilepsije diljem svijeta. Procijenili smo čimbenike koji utječu na stigmatizaciju među građanima Crne Gore. Skupinu su činile slučajno odabrane osobe u dobi od 18 do 65 godina. Ispitanici su intervjuirani upitnikom od 10 stavki, koji je bio korišten u sličnim ispitivanjima. Korištena je deskriptivna statistika, $\chi^{2}$-test i Fisherov egzaktni test kako bi se utvrdili čimbenici povezani s negativnim stavovima. Nakon isključivanja i odbijanja sudjelovanja u studiji upitnik je popunilo 1000 ljudi od kojih je 91 posto čulo za epilepsiju. Manje od polovice je znalo nekog s epilepsijom, a 31,5 posto su bili svjedoci napadaja. Jedna petina bi se protivila da se njihovo dijete igra s osobom s epilepsijom, a tri četvrtine bi se protivilo takvom braku. Četrdeset posto ispitanika smatra da ljudi s epilepsijom trebaju biti zaposleni kao i drugi. Manje od $8 \%$ ispitanika smatra da je epilepsija jedan oblik ludila. Preko $80 \%$ vjeruju da su bolesti mozga uzrok epilepsije, a 95\% misli da je glavna osobina epileptički napadaj. Opća svijest o epilepsiji u Crnoj Gori je slična onoj u drugim zemljama. Razumijevanje epilepsije je relativno dobro, ali rezultati ukazuju na to da još uvijek postoje negativni stavovi prema osobama s epilepsijom.

Ključne riječi: Epilepsija; Znanje o zdravlju, stavovi, praksa; Javno mišljenje; Društvena stigma; Crna Gora 